\title{
Nematofauna in the Adriatic Sea: review and check-list of free-living nematode species
}

\author{
Ana Travizi ${ }^{1 . *} \&$ Jasna Vidaković ${ }^{2}$ \\ I"Ruder Bošković" Institute, Center for Marine Research; G. Paliaga 5, 52210, Rovinj, \\ Croutia \\ ${ }^{2}$ Faculty oi Education, Department of Ecology; Dägera 9, 31000 Osijek, Croatia
}

\begin{abstract}
The present paper presents a collection and synthesis of data found in numerous publications on Adriatic Sea nematofana, as well as unpublished data mentioned in annotations. For this purpose, a chronological order of investigations and a general survey of the species that occurred in the Adriatic Sed are given. In all, 281 free-living nematode species comprised in 133 genera and 34 families were discerned and listed in a taxonomic review, according to their spatial distribution. In special cases, descriptions of habitat features were noted. The position of species characterized by high population densities, their importance, and contribution to the faunistic. composition of certain parts of the Adriatic were also discussed. The summary of the results of prevailing research on free-living marme nematodes serves as a tool for making distinctions concern. ing the research level and state of nematofauna knowledge in different parts of the Adriatic Sea. Northern Adriatic nematolauna has been considerably more intensively investigated than that of the Central and South Adriatic.
\end{abstract}

\section{INTRODUCTION}

Summarizing the results of nematofauna investigations (Dujardin, 1845; Berlin, 1853; Schneider, 1866; Grube, 1861; Daday, 1901; Micoletzky, 1922-1924) performed in the Mediterranean by the middle of this century, Allgen (1942) and SchuurmansStekhoven (1950) listed 65 nematode species noted in different parts of the Adriatic Sea. Most of the taxa were observed in the North Adriatic (Trieste, Rovinj, Rijekd, Kvarner area), and only few, i.e. 14 species, were found in the South Adriatic sediments (Bay of Boka Kotorska, Dubrovnik, Mljet Island, Ombla Bay).

Several later studies of phytal habitats in the sense of Remane (Wieser, 1960; Ott, 1967; Zavodnik, 1974), faunistic investigations in the Bay of Piran (Matjašic \& Stirn, 1975), orcasional studies of nematofauna in the Southern Adriatic (Sergeeva, 1981). ecological survey of meiofauna communities in Sacca di Scardovari - the Po Delta (Ceccherelli \& Cevidalli, 1981) - preceded the recent more intensive research.

At the beginning of the eighties, biogeographical and ecological research in meioand nematofauna was introduced at the Center for Marine Research at Rovinj. Since then, investigations have been performed with differing intensity and frequency at 3.5

- Addressee for all correspondence.

o Biologische Anstalt Helgoland, Hamburg 


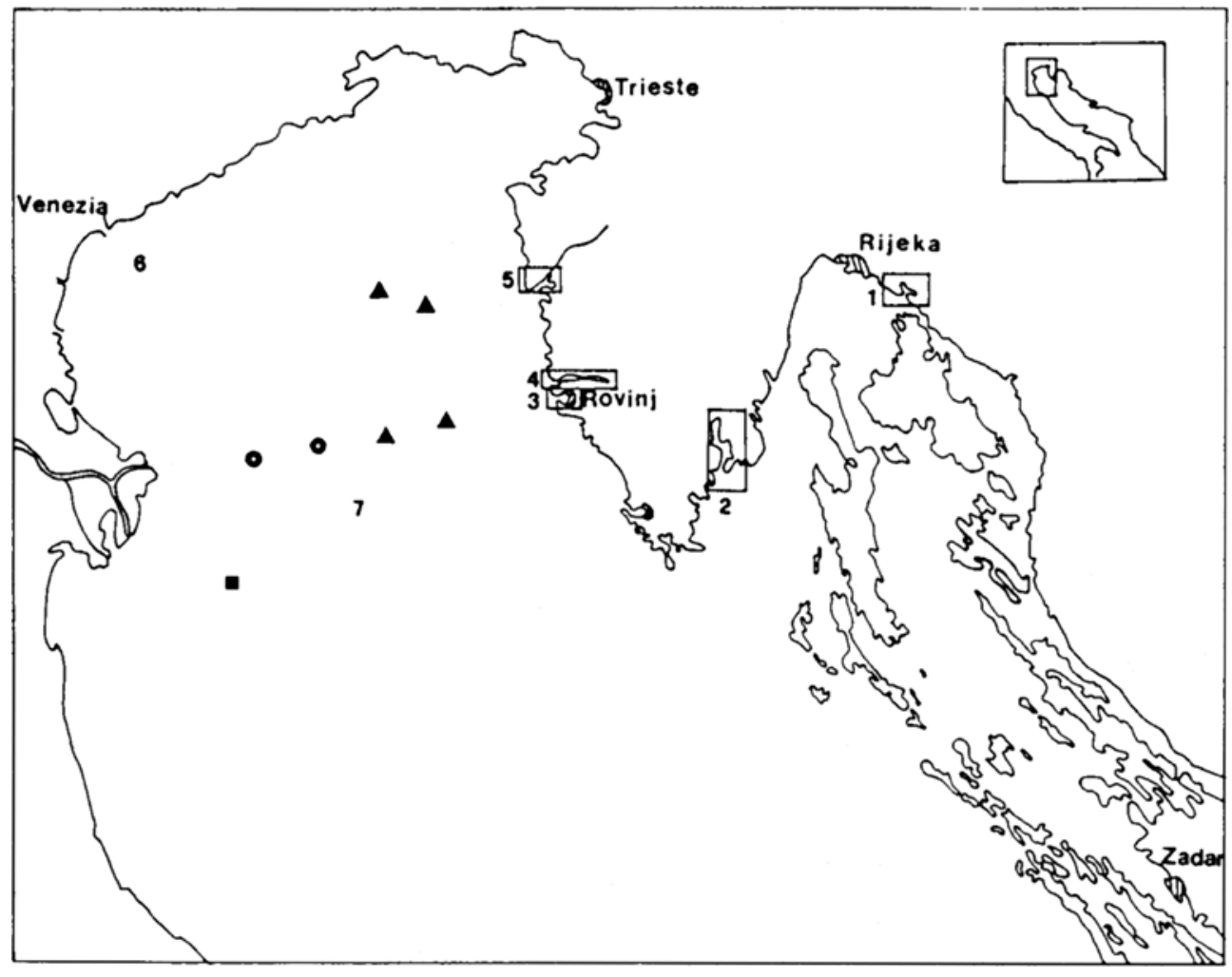

Fig. 1. Spatid distribution of North Adridtic regions, covered by quantitative nematolauna investigations: 1. Bakar Bay, 2. Raša Bay, 3. Rovinj area, 4. Lim Channel, 5. Mirna Estuary, 6. Venice Lagoon. 7. Offshore area (stations along the Rovinj-Po River mouth transect and Porec-Venezia transect characterized by $\mathbf{D i l t ,} \mathbf{A}$ silty-sand, and $\mathbf{O}$ sandy-silt sediment type)

stations within seven North Adriatic areas (Figs 1 and 2): the Rovinj ared, Lim Channel, offshore area (the Rovinj-Po River Mouth and Poreć-Venezian transects), Raša Bay, Bakar Bay, the Mirna Estuary, and Venice Lagoon (Vidakovic, 1983, 1984a, 1984b, 1987, 1988; Vidaković \& Zavodnik, 1984; Travizi \& Vidaković, 1994; Travizi, 1996). In the Central Adriatic, first investigations were performed in 1992 in the Makarska Harbour area (Travizi \& Vidakovic, in press). Many results, especially those referring to faunistic composition, have, so far, remained unpublished. Parasitic nematodes were recently checked by Hristovski \& Jardas (1983) and Petter \& Radujković $(1986,1989)$.

Since the compilations of Allgen (1942) and Schuurmans-Stekhoven (1950), the data on Adriatic sediment and phytal free-living nematodes increased significantly, but those published at all appeared mainly in local journals ignored by the broad scientific community, or lay forgotten in unpublished manuscripts, lists, and notes. Consequently, it appeared inevitable to collect existing data, with an aim to enable and promote further research. 


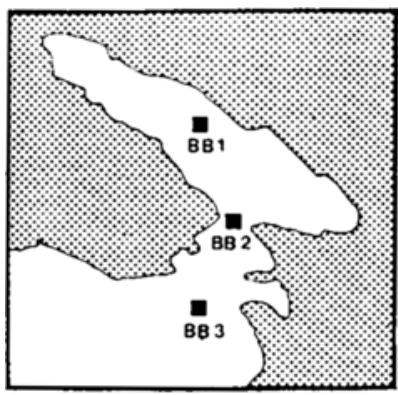

1. BAKAR BAY

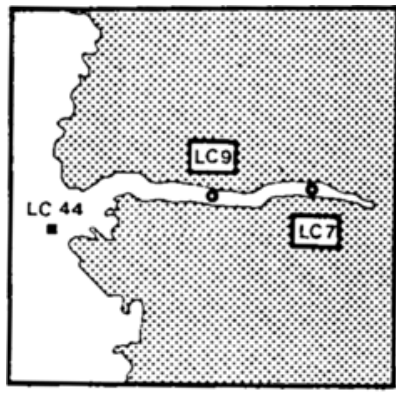

4. LIM CHANNEL

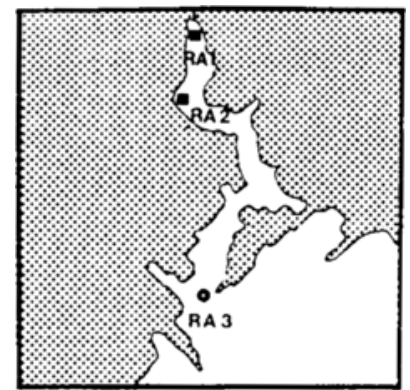

2. RASA BAY

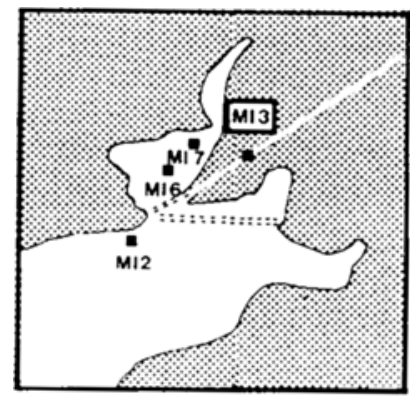

5. MIRNA ESTUARY

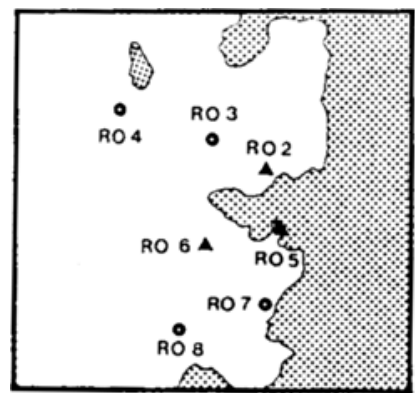

3. ROVINJ AREA

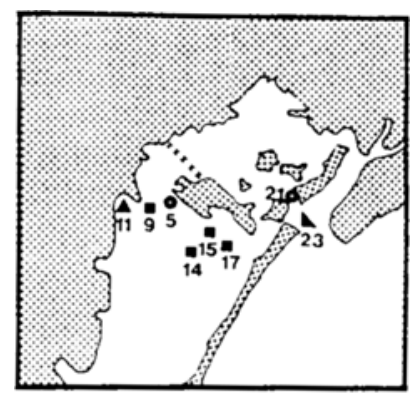

6. VENICE LAGOON

Fig. 2. Localization and sedimentological features of stations

silt, $\mathbf{A}$ silty-sand, $\mathbf{0}$ sandy-silt, - sand) in investigated areas of North Adriatic

Earlier studies presented mainly qualitative data. Structure analyses of nematofauna assemblages enabled the compilation of a preliminary survey and brief account of the nematofauna composition in recently investigated parts of the Adriatic Sea. Particular regions recognized as more or less separated areas, i.e. mainly bays, were defined as smaller biogeographical units. Within the framework of detached regions, differentiations in nematofauna structure were more or less established under consideration of the different types of sediment at particular stations. These differentiations accord with those already presented in the literature.

\section{MATERIAL AND METHODS}

Results of previous research were compiled in the form of a faunistic check-list according to species occurrence, geographical distribution, and - if available - according to habitat features and role of abundant species in regions studied. Taxonomic classification follows Lorenzen (1981). The genera within families and species within genera are in alphabetical order. Validity of scientific names was checked according to the 
"Bremerhaven Checklist of Aquatic Nematodes" (Gerlach \& Riemann, 1973, 1974) and recent systematic literature. Doubtful names are marked with an asterisk. The synonyms used in original papers, supplied by notes referring to adequate sources, are listed in the appendix. Faunistic affinities between investigated regions were calculated and expressed according to Sørensen's coefficient of similarity. The characteristic habitats are designated by symbols.

\section{RESULTS AND DISCUSSION}

More than 500 free-living nematode species were distinguished. Only 281 species, comprised in 133 genera and 34 families, were determined to species level (Table 1).

Considerable differences in the number of nematofauna species established in different regions (Fig. 3) indicated primarily unequally intensive and frequent investigations, but also differences in environmental conditions, which influence species diversity. In the Kvarner area, Gulf of Trieste, and Po Delta, free-living nematodes were noted only incidentally and occasionally in the frame of certain faunistic, ecological and biogeographical studies, which results in a low number of identified taxa in these regions. In the Bakar Bay and Mirna Estuary, a fairly low number of species were noted despite repeated sampling performed seasonally (:Mirna Estuary), or monthly (Bakar Bay) through the spring-summer period. The species poverty in these regions is most probably due to the grain size of the sediment, which is one of the main environmental factors influencing species richness, eveness, and diversity.

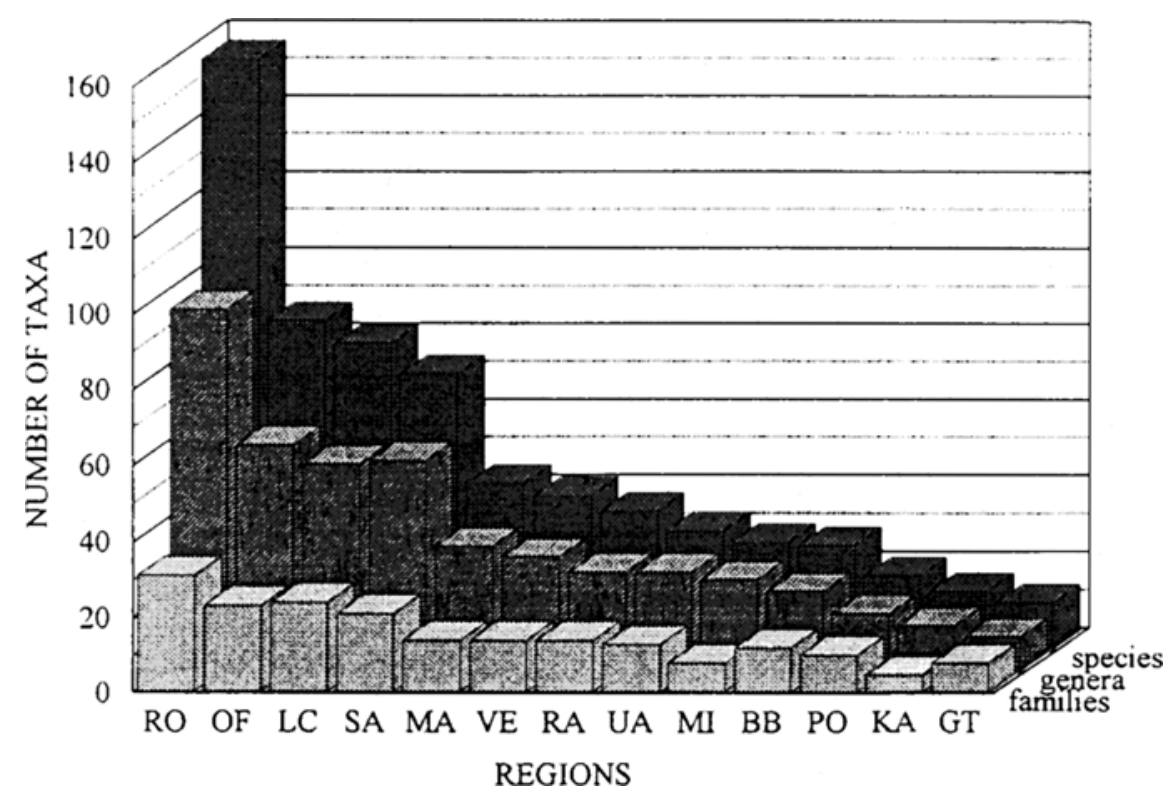

Fig. 3. Taxonomical composition of the Adriatic Sea nematofauna 
Table 1. Check-list of Adriatic Sea nematofauna. Investigated regions: PO - Po Delta, VE - Venice Lagoon, OF - offshore area (Ruvinj-Po River mouth transect, Poreć-Venezia transect), MI - Mirna Estuary, LC - Lim Channel, RO - Rovinj ared, RA - Rasa Bay, BB - Bakar Bdy, GT - Gulf of Trieste, KA - Kvarner area, MA - Makarska harbour area, SA - South Aciriatic, UA - Undelined positions, habitat characteristics (Ph - phytal, S - sand, Ss - sandy-silt, sS - silty-sand, s - silt, Eu - all types of sediment)

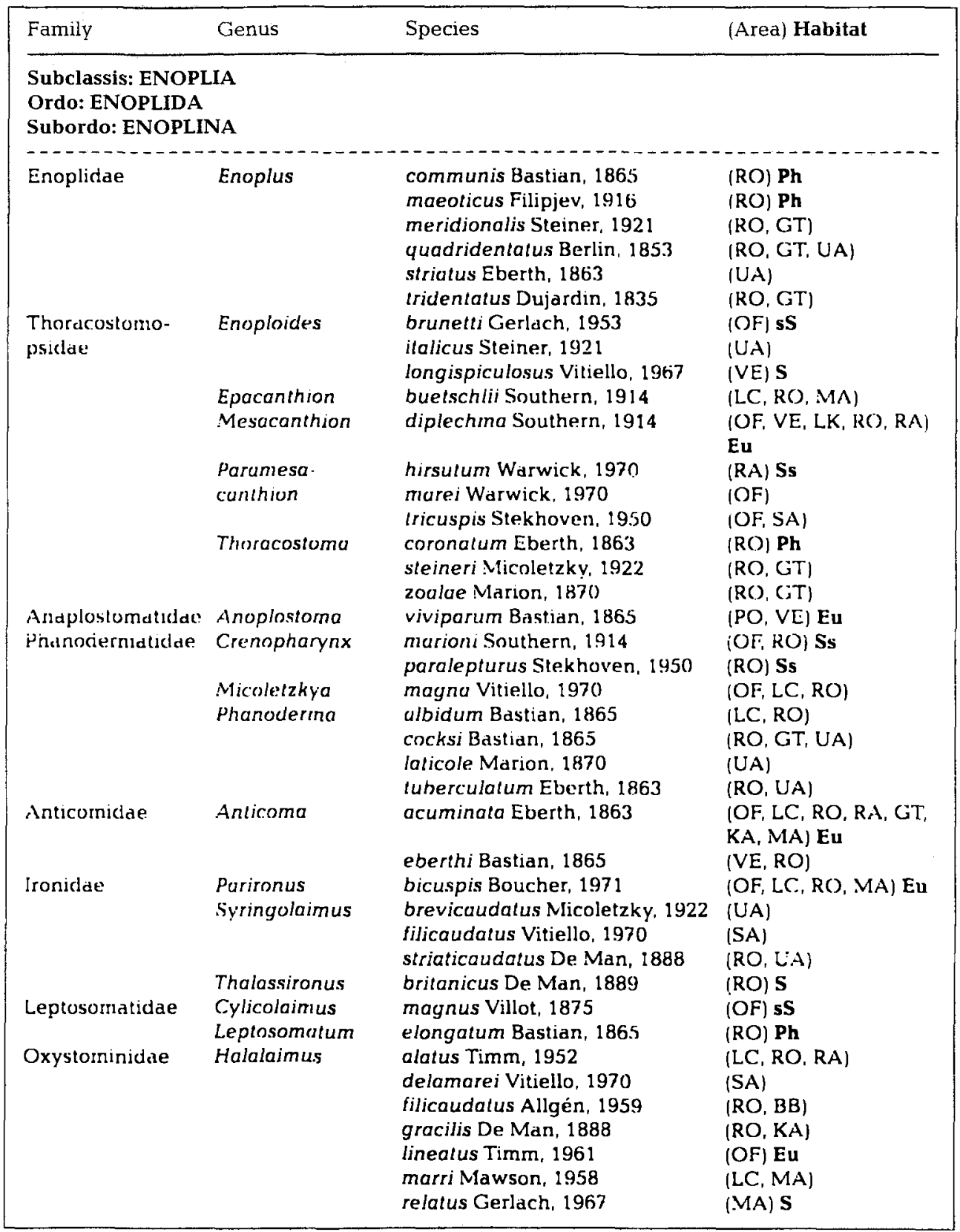


Iable 1 (continued)

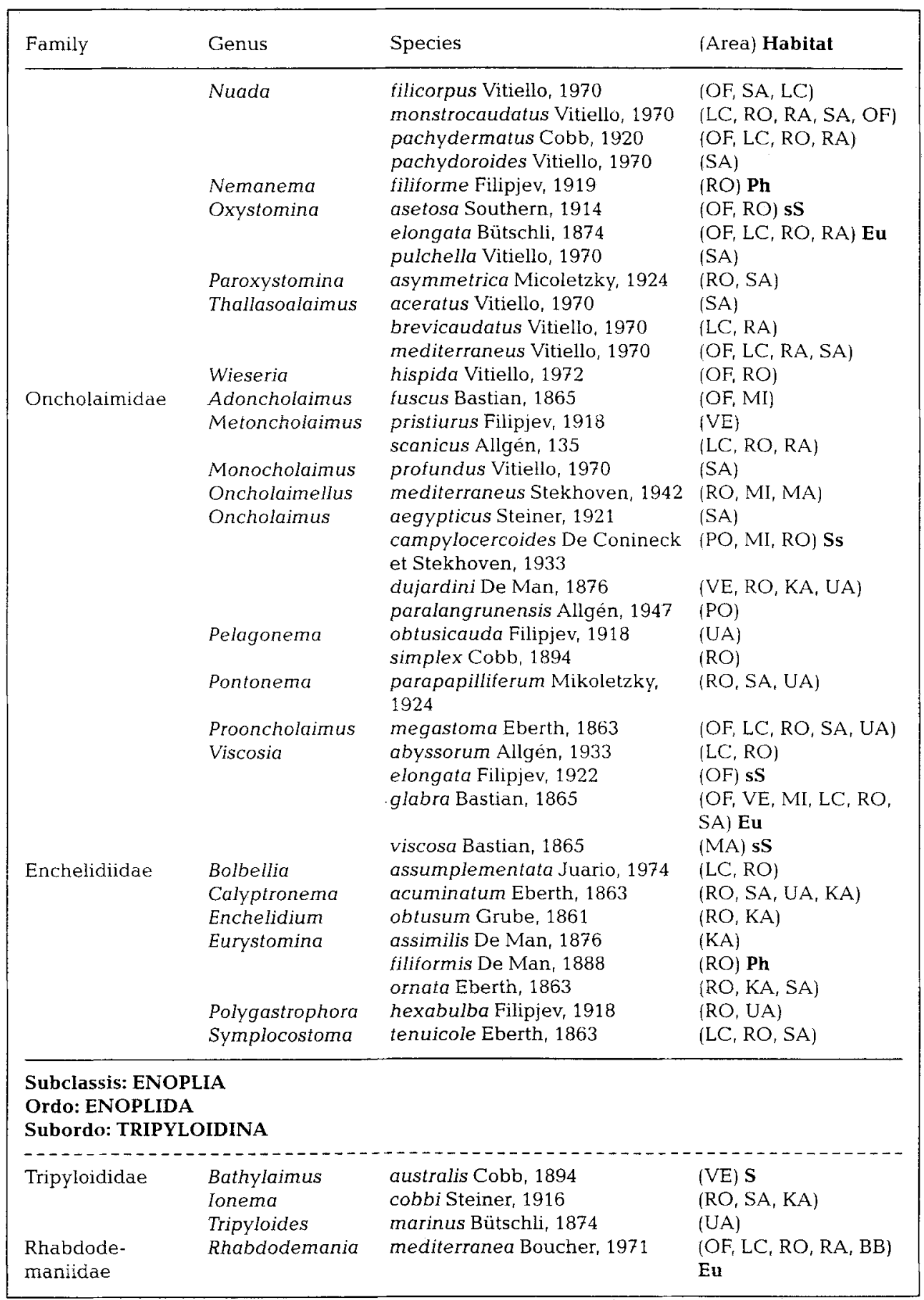


Table 1 (continued)

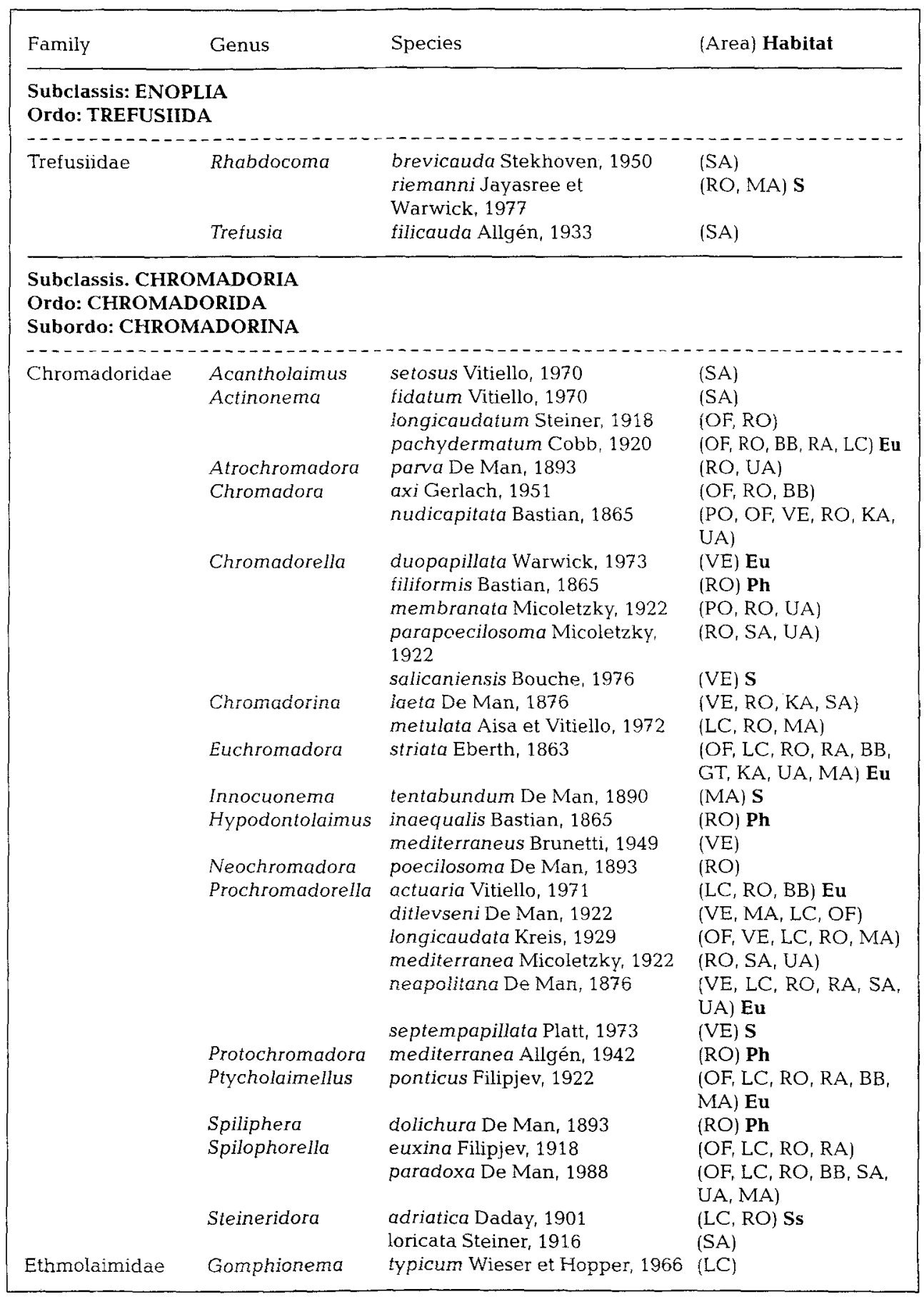


Table 1 (continued)

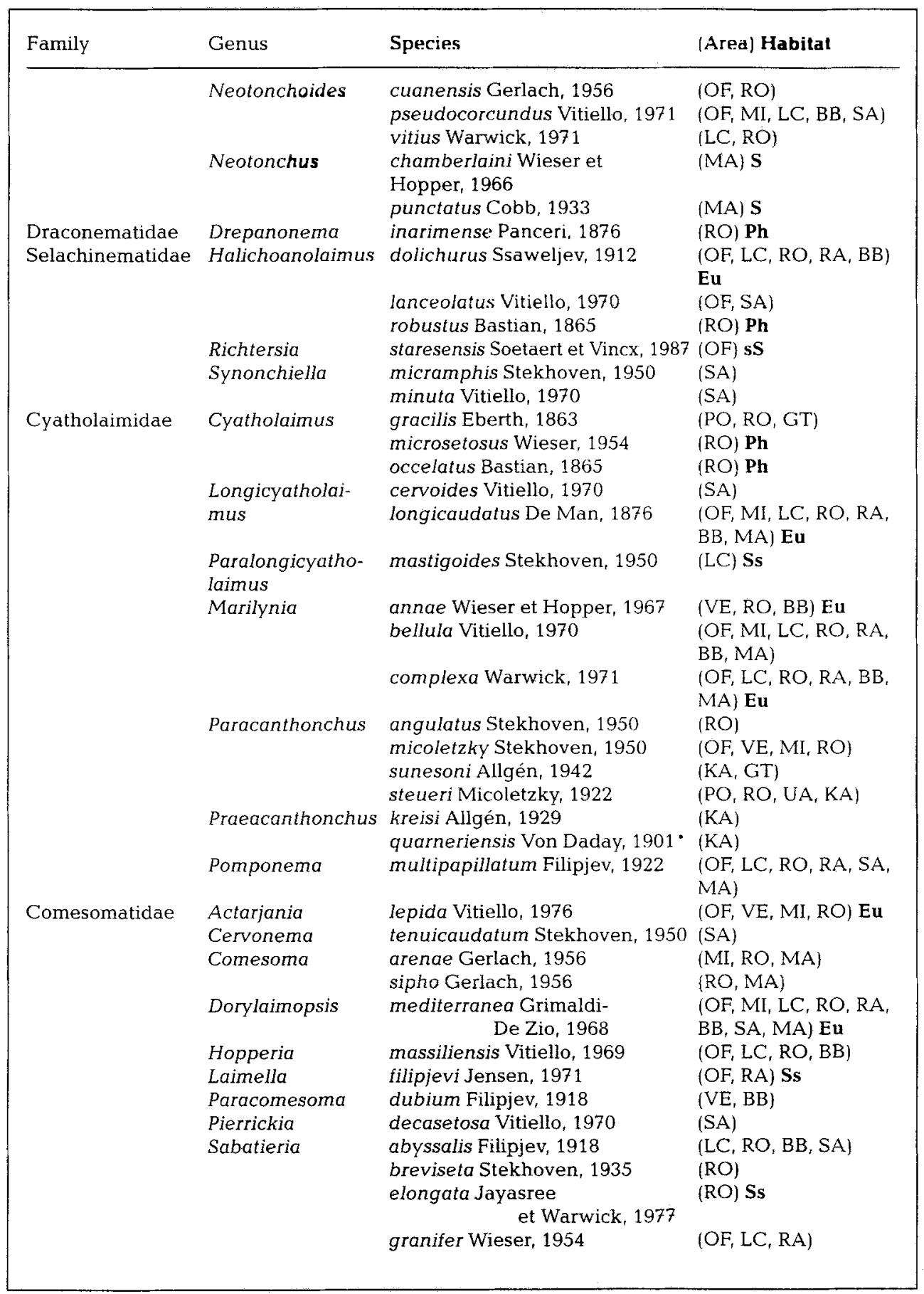


Table 1 (continued)

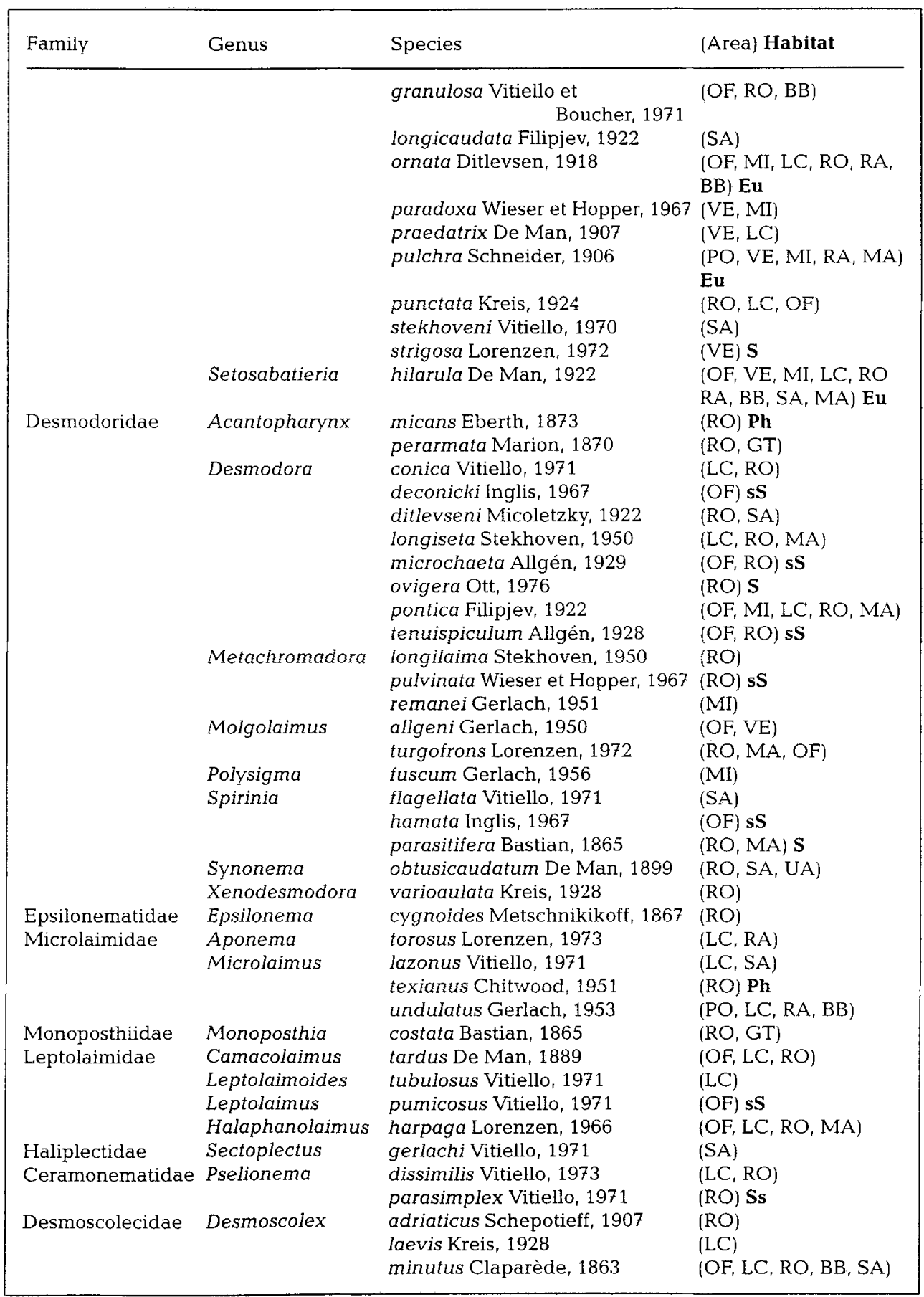


Table 1 (continued)

\begin{tabular}{|c|c|c|c|}
\hline Family & Genus & Species & (Area) Habitat \\
\hline & Greeffiella & oxycaudata Greff, 1869 & (RO) \\
\hline Monhysteridae & Monhystera & heteropurva Micoletzky, 1924 & (UA) \\
\hline \multirow[t]{24}{*}{ Xyalidae } & Cylindrotheristus & acidus Vitiello, 1971 & $(S A)$ \\
\hline & & calceolatus De Coninck et & $(P O)$ \\
\hline & & Stekhoven, 1933 & \\
\hline & & fistulatus Wieser et Hupper, 1967 & $(\mathrm{MA}) \mathrm{S}$ \\
\hline & & haeoticus Filipjev, 1922 & (LC) \\
\hline & & normandicus De Man, 1890 & $\begin{array}{l}\text { (PO, MI, LC, RO, RA) } \\
\text { Eu }\end{array}$ \\
\hline & & paralortus Vitiello, 1971 & (LC, SA) \\
\hline & & pseudolortus Vitiello, 1971 & $(S A)$ \\
\hline & & tenuispiculum Ditlevsen, 1958 & $\{\mathrm{PO}\}$ \\
\hline & Daptonema & conicum Filipjev, 1922 & $\begin{array}{l}\text { (OF, MI, LC, RO, RA, } \\
\text { MA) Eu }\end{array}$ \\
\hline & & furcatum Juario, 1974 & (VE) \\
\hline & & longissimecaudatum Kreis, 1935 & (VE, MI, RO) Eu \\
\hline & Mesotheristus & setosus Bütschli, 1874 & (PO, RO, UA) \\
\hline & Metadesmolaimus & caniculus Wieser et Hopper, 1967 & (VE) $\mathbf{S}$ \\
\hline & & coronatus Stekhoven, 1950 & (VE) Eu \\
\hline & & gelana Warwick et Platt, 1973 & $(\mathrm{RO})$ \\
\hline & & varians Lorenzen, 1972 & (MI, RO) \\
\hline & Paramonhystera & $\begin{array}{l}\text { paranormandica Micoletzky, } \\
1922\end{array}$ & $(\mathrm{RO}, \mathrm{SA}, \mathrm{UA})$ \\
\hline & Pseudotheristus & circulus Vitiello, 1971 & $(\mathrm{LC}, \mathrm{SA})$ \\
\hline & Steineria & aegyptica Andrássy, 1959 & $(\mathrm{RA})$ \\
\hline & Theristus & bastiani Wieser, 1972 & $(\mathrm{OF}, \mathrm{VE})$ \\
\hline & & flevensis Stekhoven, 1935 & $(\mathrm{PO})$ \\
\hline & & inermis Gerlach, 1953 & $(\mathrm{SA})$ \\
\hline & & papillatus Murphy, 1965 & $(\mathrm{RO})$ \\
\hline \multirow[t]{7}{*}{ Sphaerolerimidae } & Sphaerolaimus & dispar Fílipjev, 1918 & $\begin{array}{l}\text { (OF, MI, LC, RO, RA, } \\
\text { BB, MA) Eu }\end{array}$ \\
\hline & & glaphyrus Vitiello, 1971 & (OF, RA) \\
\hline & & gracilis De Man, 1876 & $(\mathrm{OF}, \mathrm{RO})$ \\
\hline & & macrocirculus Filipjev, 1918 & $\begin{array}{l}\text { (PO, OF, VE, MI, LC, } \\
\text { RO, RA, BB, SA) Eu }\end{array}$ \\
\hline & & minutus Vitiello, 1918 & $(\mathrm{SA}, \mathrm{LC}, \mathrm{OF})$ \\
\hline & & ostreae Filipjev, 1918 & (OF, LC, RO, RA, MA) \\
\hline & & profundus Vitiello, 1971 & (SA) \\
\hline \multirow[t]{4}{*}{ Siphonolaimidae } & Anguillulina & mediterranea Micoletzky, $1923^{*}$ & $(\mathrm{RO}, \mathrm{SA})$ \\
\hline & Astomonema & otti Vidaković et Boucher, 1987 & $(\mathrm{OF}, \mathrm{RA}, \mathrm{BB})$ \\
\hline & Siphonolaimus & elongatus Stekhoven, 1950 & $(\mathrm{OF}, \mathrm{VE}, \mathrm{LC}, \mathrm{RA}, \mathrm{BB})$ \\
\hline & & weismani Steiner, 1916 & $(\mathrm{OF}, \mathrm{LC}, \mathrm{RA})$ \\
\hline \multirow[t]{8}{*}{ Linhomveidde } & Anticyclus & gigas Vitiello, 1969 & $(\mathrm{OF}, \mathrm{SA})$ \\
\hline & & pachyamphis Wieser, 1956 & (SA) \\
\hline & Didelta & scutelatum Vitiello, 1969 & (OF, RA) Ss \\
\hline & Disconema & minutum Vitiello, 1969 & $(\mathrm{SA})$ \\
\hline & Linhomoeus & hirsutus Bastian, 1865 & (RO) $\mathbf{P h}$ \\
\hline & Metalinhomoeus & biformis Juario, 1974 & $\begin{array}{l}\text { (OF, VE, MI, LC, RO, } \\
\mathrm{MA})\end{array}$ \\
\hline & & biratus Vitiello, 1969 & (OF, MA) \\
\hline & & breviseta Stekhoven, 1950 & (LC) \\
\hline
\end{tabular}


Table 1 (continued)

\begin{tabular}{|c|c|c|c|}
\hline Family & Genus & Species & (Ared) Habitat \\
\hline Axonolaimudae & $\begin{array}{l}\text { Axonoluimus } \\
\text { Odontophora } \\
\text { Parudontophora } \\
\text { Araeolaimoides } \\
\text { Araeolaimus }\end{array}$ & 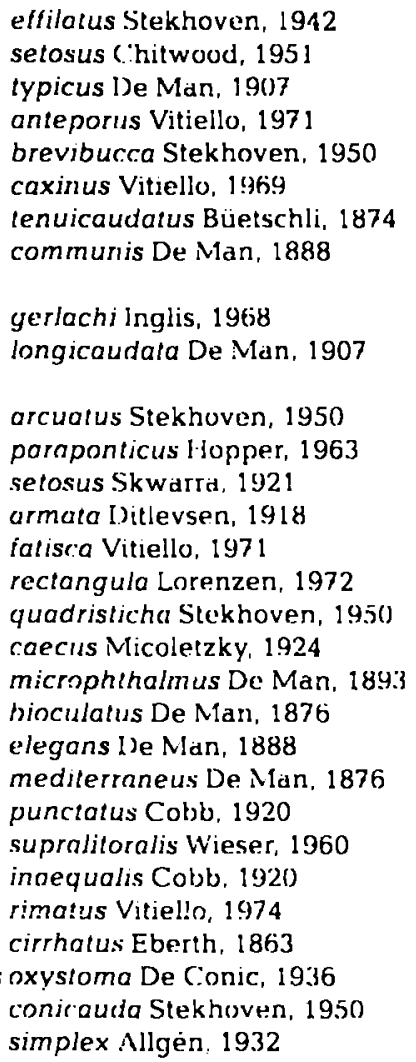 & $\begin{array}{l}\text { (RO) Ss } \\
\text { (RO, RA, BB) Eu } \\
\text { (VE, MI) } \\
\text { (OF, VE, RO) } \\
\text { (OF, RO, MA) } \\
\text { (OF) SS } \\
\text { (LC) } \\
\text { (OF, PO, VE, MI, LC, } \\
\text { RO, RA, MA) Eu } \\
\text { (OF, MA) } \\
\text { (OF, PO, VE, MI, LC, } \\
\text { RO, RA, SA, MA) Eu } \\
\text { (LC) S } \\
\text { (RO, MA) } \\
\text { (OF, SA) } \\
\text { (PO) } \\
\text { (SA) } \\
\text { (VE) S } \\
\text { (PO) } \\
\text { (UA) } \\
\text { (RO; Ph } \\
\text { (RO, SA, UA) } \\
\text { (LC) } \\
\text { (RO, SA, UA) } \\
\text { (SA) } \\
\text { (RO) Ph } \\
\text { (OF, SA) } \\
\text { (NA) S } \\
\text { (RO) Ph } \\
\text { (RO) Ph } \\
\text { (LC) } \\
\text { (OF) }\end{array}$ \\
\hline
\end{tabular}

According to Tietjen (1977), mud is the common name tor sediment types characterized by a high $(64-75 \%)$ share of silty-clay content, and it is distinguished by high nematofaund density and dominance, but also by low species diversity and endemism in comparison to sandy and mixed types. All the stations investigated in Bakar Bay and Mirna River Estuary are characterized by the muddy sediment type. A sampling of similar intensity was carried out in Venice Lagoun (seasonally) and Raša Bay (monthly during the summer-autumn period), but compared to previous regions, the number of identified species was almost twice as high. In Venice Lagyoon this could be the result of the relatively high number of research stations, while in both cases, certain stations siturited at locations with a higher diversity potential (mixed and sandy sediment types) probably play a more significant role. Relatively high taxonomic diversity in the Makarska harbour area (one-fold sampling at four stations) also could be explained by the sandy nature of the habitat. The relatively high diversity in the North Adriatic 
offshore area, higher than in simlar frequently sampled regions, may be due to differences in the heterogeneily of the environmental parameters. In the South Adriatic, meiofauna sampling performed during the last decades of the $19^{\text {th }}$ and first decades of the $20^{\text {in }}$ centuries resulted in the detection of only 14 nematocle species in a fairly scattered selection of localities. More recent investigations at different, mainly mixed types of sediment in this part of the Adriatic showed a distinct increase in the number of taxa detected, in comparison to the regions distinguished by similar granulometric characteristics. The Lim Channel area stands out because of the high number of taxa noted there; this is most probably due to the high frequency of sampling (monthly, during a two-year period), which increases the probability of detecting rare species and those of low quantity, and enables the registration of species with short life cycles. Nematofauna samplings in the Rovinj area have been performed at irregular intervals from the start, but cuntinuous, long-term investigations have never been carried out there. Almost $60 \%$ of the species recorded from the Adriatic have been found near the research station in Rovinj, an area of heterogeneous sediments and phytal habitats that has been studied for more than a hundred years.

Differing intensity and frequency of sampling negatively influences the faunistic affinity factor between certain pairs of investigated areas. Environmental conditions, especially sediment grain size, play the most important role in their level of similarity.

Table 2. Faunistic affinity between investigated regions: PO - Po River Delta, VE - Venice Lagoon, OF - offshore area, MI - Mirna River Estuary, LC - Lin Channel, RO - Rovinj area, RA - Rasa Bay, BB - Bakar Bay, CiT - Gulf of Trieste, KA - Kvarner area, MA - Makarska harbour area, SA - South Adriatic

PO VE GT OF MI LC RO RA BB KA MASA

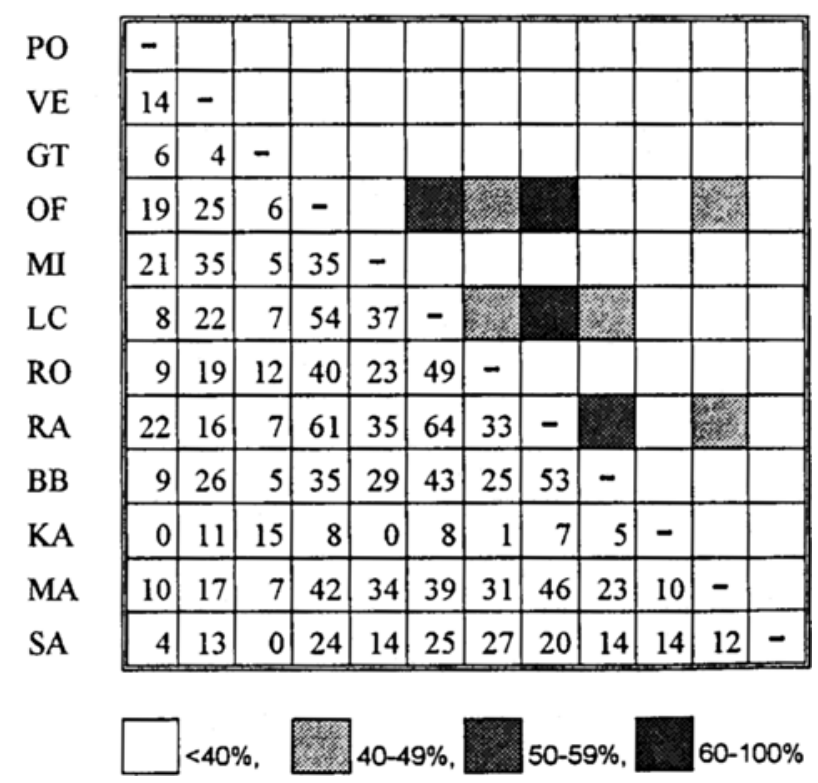


Sørensen's coefficient of similarity indicates widely differing rates of faunistic dffinity in nematofauna composition varying from 0 to $64 \%$ (Table 2). A very low similarity is detected between nematofauna assemblages in the Gulf of Trieste and Kvarner area on the one hand, and all other regions on the other. This suggests the unsuitability of this method for application in insufficiently investigated regions in comparison with those that are much better known. In comparison to the areas distinguished by a low number of species (mainly annotations), other areas characterized by more frequent and/or more systematic nematofauna research showed a considerably high level of faunistic similarity. The greatest affinity $(64 \%)$ was established between the Lim Channel and Raša Bay nematofauna, which could be explained by similarities in the main environmental features, i.e. sediment type, depth, exposure, abundance of natural microhabitats, number of fresh water springs, etc. Fairly high faunistic affinity was noted between the offshore area and Raśa Bay $(61 \%)$, the offshore area and Lim Channel $(54 \%)$, and between Raša Bay and Bakar Bay $(5.3 \%)$. If we ignored the poorly investigated Kvarner area, the Gulf of Trieste, and the Po River Delta, affinity calculated for other pairs of investigated regions mainly ranged between 12 and $39 \%$.

Despite the presence of all basic sediment types, sampling during the course of all seasons, and numerous research stations, the nematofaund composition in Venice Lagoon showed a relatively low affinity to that of the majority of all other regions. An exception, to a certain degree, is the moderate level of nematofauna affinity $(35 \%)$ to the Mirna Estuary. Considering the significant differences between these two regions, expressed by different sources of stress conditions, i.e. waste-water overcharge in Venice Lagoon, and the specific brackish environment in the Mirna River Estuary, the relatively high similarity coefficient could probably be explained by the presence of many euryoecious species which are addpted to a great variance in environmental factors, and by the very low depths $(0.5-3 \mathrm{~m})$ of the compared regions. The fairly low faunistic affinity between the North and South Adriatic regions (12-27\%) could be expected, considering the differing and specialized environmental conditions in these parts of the Actriatic Sea.

The most recent examinations show that the taxonomical structure of free-living marine nematodes in the Adriatic Sea are characterized by the presence of 34 families, among which Chromadoridae (32 species, 16 genera) are the most diverse (Fig. 4). They are followed by Comesomatidae, Xalidae, Desmodoridae, Oxystominidae, Linhomoeidue, Oncholaimidae, and Cyatholaimidae, with the greatest richness and diversity in the lower taxa (Fig. 4). On the other hand, about $27 \%$ of the families are represented by only one genus, and about $36 \%$ of the noted genera comprise only one species. Less than $10 \%$ of genera show somewhat greater diversity, comprising five (Araeolaimus, Chromadorella, and Metalinhomoeus), six (Enoplus and Prochromadorella), seven (Halalaimus and Sphaerolaimus), eight (Cylindrotheristus), and nine species (Desmodora), while only the genus Sabalieria included more than ten species.

It is well known that different types of sediment are generally characterized by a predominance of specific families and particular nematofauna composition. According to Heip et al. (1982), the prevailing families in silty sediment are Comesomatidae and Linhomoeidae; in silty-sand sediments and fine sands Comesomatidar, Monhysteridae, Desmodoridae, and Axonolaimidae; and in medium sands usually Monhysteridae, Desmodoridae, and Chromadoridae. Considering the granulometric features of 


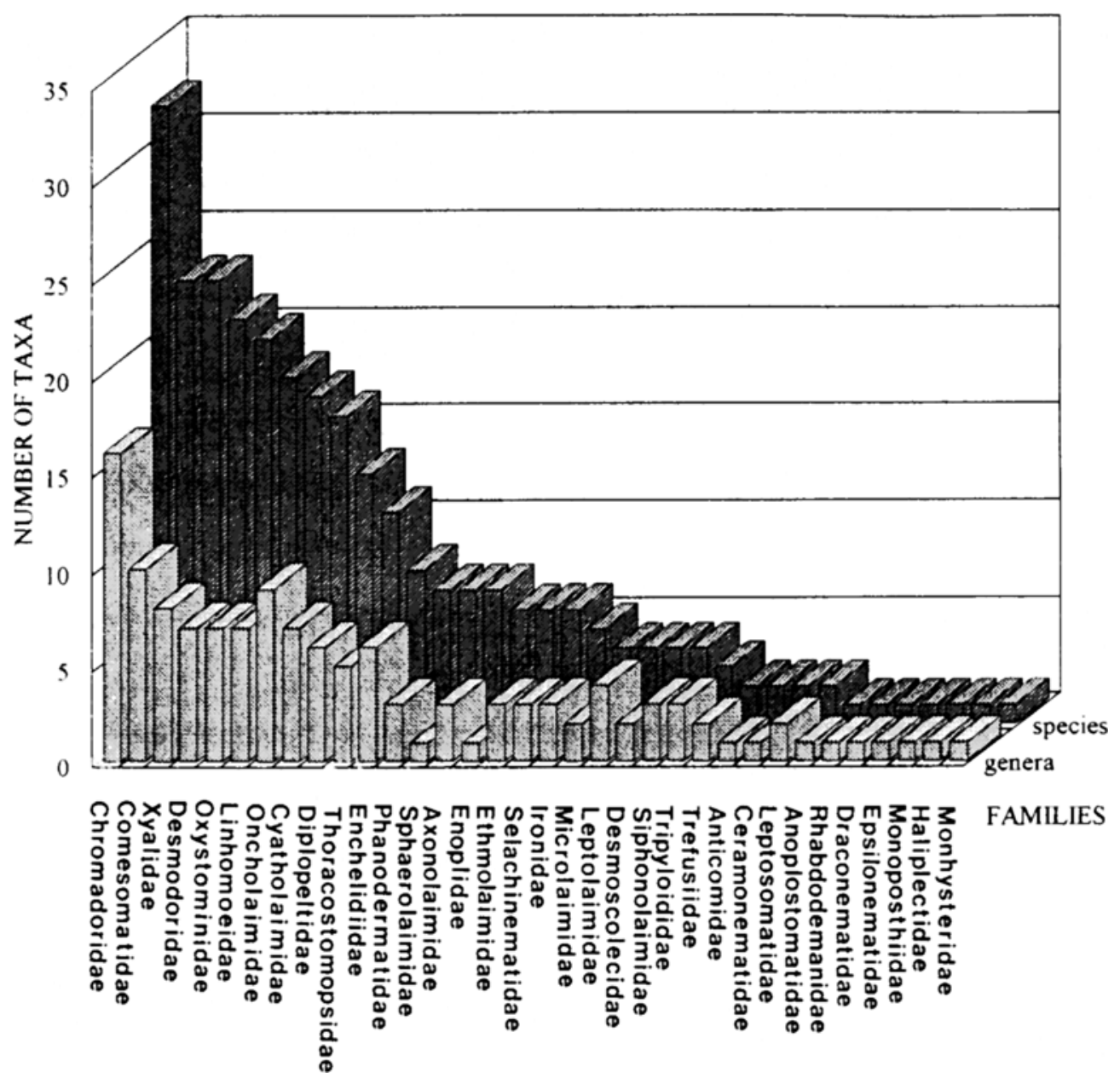

Fig. 4. Composition of nematofauna in the resedrch areas. Families dre listed in order of dom nance

the separate stations, a correlation with this statement could be established in most cases.

With regard to the importance of particular species in nematofauna composition, in all areas studied, only few species (3-6) were distinguished by their relatively high percent abundance $(5-38 \%)$. All other species together summed up to about $80-95 \%$ of the total nematofaund, although representing only $22-58 \%$ of the total density, which reflects very low abundance values for each species concerned (Fig. 5). Similar characteristics of nematofauna spatial distribution, especially in muddy sediments, were also noted in other Mediterranean regions (Vitiello, 1974). Based on the prevailing data, the following species could be distinguished as the main components of nematofauna 


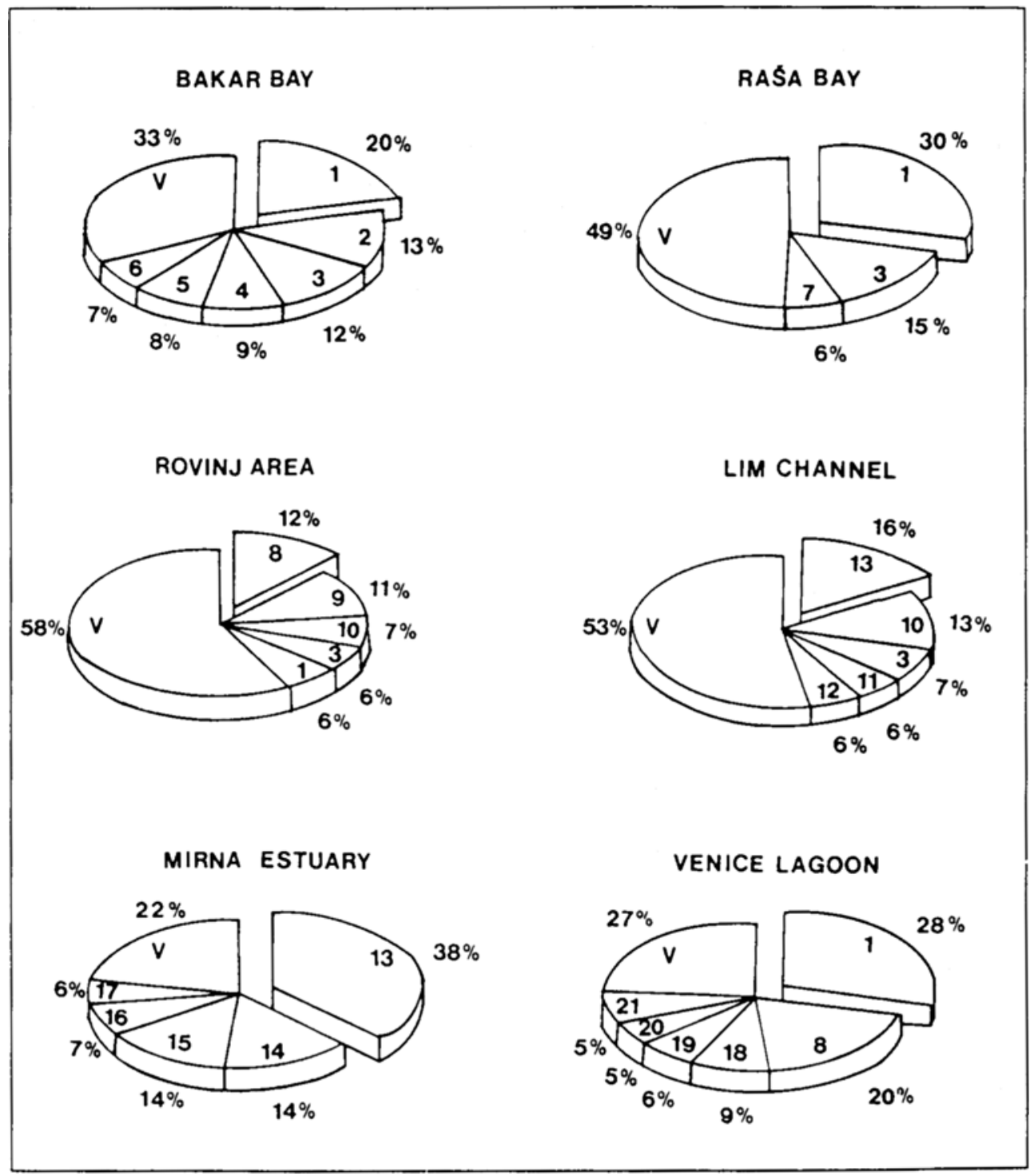

Fig. 5. Spatial distribution of Nolth Adriatic nematofauna. Species composition: 1. Dorylaimopsis mediterranea, 2. Astomonema otti, 3. Marilynia complexa, 4. Sabatierio ornata, 5. Actinonema pachydermalum, 6. Halalainus filicaudatus, 7. Sabatieria granulosa, 8. Terschellingia longicouduta, 9. Metacyatholaimus sp., 10. Ptycholaimellus ponticus, 11. Hopperia massiliensis, 12. Sabatieria abyssalis, 13. S. pulchra, 14. S. paradoxa, 15. Polysigma fuscum, 16. Actariania lepida, 17. Sphoerolaimus macrocirculus, 18. Molgolainus ullgeni. 19. Selosabatieria hilurulu, 20. Terschellingia communis, 21. Metalinhomveus biformis, $\mathrm{V}$ - other species (abundance $<5 \%$ "' 
assemblages in certain areas of the North Adriatic: Actarjania lepida, Actinonema pachydermatum, Astomonema otti, Chromadorella salicaniensis, Dorylaimopsis mediterranca, Halalaimus filicaudatus, Hopperia massiliensis, Marilynia complexa, Metalinhomoeus biformis, Molgolaimus allgeni, Ptycholaimellus ponticus, Polysigma iuscum, Prochromadorella longicauduta, Sabatieria abyssalis, S. granulosa, S. paradoxa, S. ornatu, S. pulchra, Setosabatieria hilarula, Sphaerolaimus macrocirculus, Terschellingia communis, and $T$. longicaudata.

Excepting Chromadorella salicaniensis, which was noted only in sandy sediment, all species citied above were noted in different types of sediment, and some of them in all types. Generally, of all species identified in the Adriatic Sea, more than half of them $(6 . \%)$ were noted in differunt, or in all $(11 \%)$ types of sediment. Meanwhile, certain species were found solely in one certain type of habitat (Table 1, hold signs); thus seventeen $(6 \%)$ species were noted in sand, thirteen $(5 \%)$ in silty-sand, another thirteen $(5 \%)$ in sandy-silt, two $(1 \%)$ in silt, and twentyone $(7 \%)$ in phytal habitats.

Sirnilar to other regions in the world seas, the Adriatic nematofaund has been only partially studied, mostly in areas around the sites of local scientific institutions. The studies of South and Central Adriatic nematofauna were found to be quite scarce and insufficient. Consequently, northern Adriatic nematofauna is by far the most well known, even though the study of offshore and sandy sediments is still insufficient. Nevertheless, this insufficient knowledge of the nematofauna of exposed coastal habitats, offshore sediments, and especially of sandy bottoms, suggests a considerably greater diversity and richness in the North Adriatic.

\section{LITERATURE C.ITED}

Allg̣er. C., 9942. Dic freilebenden Nematodun des Millelmeeres. - Zuol. Jb. (Syst. Ökol. Ciengr. Tiele) $76,1-102$.

Berln, W., 1853. Über cinen neuen Wurm aus der Cruppe der Angu:!lwide. Enoplus quudridenalus. Mullers Arch. Anat. Physiol. 431-441.

Ceccherelli, V U. \& Cevidalli, F., 1981. Preliminary observations on the meiobenthos of the "Sdcca di Scarduvari" (l'o delta) with particular reference to Nematodes and Copepods. - Quad Lab Tecnol. Pesca, Ancona 3, 26j-281.

Daday, E. von, 1901. Freilebende Nematoden aus dem Quarnero. - Természetr. Füz. 24, 433-457.

Dujardin, F. 1845. Historie naturelle des Helminthes ou versintestinales. Libraire encyclopèdique de Koret (Suttes à Buffon), Paris, 652 pp.

Gerlach, S. A. \& Riemann, F, 1973. The Bremerhaven checklist of aquatic nematodes. - Veroff Inst. Meeresforsch. Bremerh. [Suppl.] 4, 1-734.

Grube, A. E., 1861. Ein Ausílug nach Triest und dem Quarnero. Nicolaische Verlagsb., Berlin, 17.5 pp.

Heip, $\therefore$., Vinc:x, M., Smol, N. \& Vranken, G., 1982. The sysiematics and ecology of free-living marine nematodes. - Helminthol. Abstr. (Ser. B) 5l, 1-31.

Hristovski, N. D. \& Jardas, I., 1983. A contribution to the knowledge of the helminth faund of fishes from the coastal waters of the Mid-dalmatian insular area of the Adriatic sea. - Acta adriatt. 24, 179-191.

Lorenzen, S., 1981. Entwurf eines phylogenetischen Systems der freilebenden Nematoden. Veröff. Inst. Meeresforsch. Bremerh. (Suppl.) 7, 1-472.

Micoletzky, H., 1922/1924. Neu freilebende Nematoden aus Suez. - Sber. Akad. Wiss. Wien (Math.-nat. K1.) 1, 131-133.

Matjašič. J. \& Stirn, J., 1975. Flora in favna severnega Jadrana. Prispevek I., SAZU Ljubljana.

Ott, J., 1967. Vertikalverteilung von . Vematoden in Beständen rordadria:ischer Sargassaceen. Helgoländer wiss. Meeresunters. 15, 412-428. 
Petter, A. J. \& Radujković, B. M., 1986. Nématodes parasites de poissons en Méditerranée occidentale. - Bull. Mus. natn. Hist. nat. 10, 347-369.

Petter, A. J. \& Radujković, B. M., 1989. Parasites des poissons marins du Monténégro. Nematodes. - Acta adriat. 30, 195-236.

Schneider, A., 1866. Monographie der Nematoden. Riemer, Berlin, $357 \mathrm{pp}$.

Schuurmans Stekhoven, J. H. Jr., 1950. The freeliving marine nemas of the Mediterranean. I. The Bay of Villefranche. - Mem. Inst. r. Sci, nat. Belg. 37, 1-220.

Sergeeva, N. G., 1981. Distribution of free-living marine nematodes from south Adriatic. In: Evolution, taxonomy, morphology and ecology of free-living nematodes. Ed by T. A. Platonova and S. Ya. Tsalolikhin. Academy of Sciences of the USSR, Zoological Institute, Leningrad, 77-79.

Tietjen, J. H., 1977. Population, distribution and structure of the free-living nematodes of Long Island Sound. - Mar. Biol. 43, 123-136.

Travizi, A., 1996. Posljedice anoksije na meiofaunu i nematofaunu sedimenata sjevernog Jadrana. Ph.D. Thesis, Zagreb, $303 \mathrm{pp}$.

Travizi, A. \& Vidaković, J., 1994. An evaluation of eutrophication effects on northern Adriatic meio- and nematofauna communities. - Period. biol. 96, 469-473.

Travizi, A. \& Vidaković, J., 1998. Prvi prilog nematofauni makarskog primorja. - Ekol. monogr. 5, (in press)

Vidakovic, J., 1983. The influence of raw domestic sewage on density and distribution of meiofauna. - Mar. Pollut. BuIl. 14, 84-88.

Vidaković, J., 1984a. Meiofauna of silty sediments in the coastal area of the North Adriatic, with special reference to sampling methods. - Hydrobiologia 118, 67-72.

Vidakovic, J., 1984b. Sea bottom meiofauna in the area of Rovinj (the Northern Adriatic Sea, Yugoslavia). - Thalassia jugosl. 20, 1-11.

Vidaković, J., 1987. Meiofauna i asocijacije nematoda u muljevitom sedimentu morskog dna Limskog kanala. Ph.D. Thesis, Zagreb, 168 pp.

Vidaković, J., 1988. Meio- and nematofauna from Raša Bay (North Adriatic Sea, Yugoslavia). - Vie Milieu 38, 213-220.

Vidakovic, J. \& Zavodnik, D., 1984. Benthos of the Po river mouth - subject to stress conditions? J. Etud. Pollut., Lucerne, C.I.E.S.M. 7, 805-809.

Vitiello, P., 1974. Peuplements de Nématodes marins de fonds envasés de Provence. I. Sédiments vaseux de mode calme et vases terrigènes côtières. - Annls Inst. océanogr. Paris 50, 145-172.

Wieser, W., 1960. Algenbewohnende Nematoden aus Rovinj (Istrien). - Zool. Anz. 164, 82-88.

Zavodnik, D., 1974. Dynamics of the littoral phytal on the West coast of Istria. - Razpr. slov. Akad. Znan. Umet. 3, 255-300. 